\title{
Cement with silica fume and granulated blast-furnace slag: strength behavior and hydration
}

\author{
V.L. Bonavetti凶, C. Castellano, H. Donza, V.F. Rahhal, E.F. Irassar \\ Universidad Nacional del Centro (Buenos Aires, Argentina) \\ $\triangle$ vbonavet@fio.unicen.edu.ar
}

Received 26 June 2013

Accepted 3 March 2014

Available on line 15 July 2014

\begin{abstract}
This paper analyses the influence of portland cement replacement by silica fume (up to 10\%) and/ or granulated blast furnace slag (up to $70 \%$ ) on the hydration cement (XRD, heat of hydration, non evaporable water content and calcium hydroxide content) curing under sealed conditions and their effect on the mechanical strength.

The obtained results indicate that binary cements containing silica fume and ternary cements there was a significant increase of hydration rate at early age. At later ages, most of studied cements have an equivalent or greater strength that those obtained in the plain portland cement.
\end{abstract}

KEYWORDS: Silica fume; Blast furnace slag; Hydration products; Mechanical strength; Central composite design

Citation / Citar como: Bonavetti, V.L.; Castellano, C.; Donza, H.; Rahhal, V.F.; Irassar, E.F. (2014). Cement with silica fume and granulated blast-furnace slag: strength behavior and hydration. Mater. Construcc. 64 [315], e025 http:// dx.doi.org/10.3989/mc.2014.04813.

RESUMEN: Cementos con humo de sílice y escoria granulada de alto horno: comportamiento resistente e hidratación. En este trabajo se analiza la influencia de la incorporación al cemento portland de humo de sílice (hasta 10\%) y/o escoria granulada de alto horno (hasta 70\%) sobre la hidratación (DRX, calor de hidratación, contenido de agua no evaporable y de hidróxido de calcio), bajo condiciones de curado sellado y su incidencia sobre la resistencia mecánica.

Los resultados obtenidos indican que en los cementos binarios con humo de sílice y en los cementos ternarios se produce un importante aumento de la velocidad de hidratación en las primeras edades, mientras que a edades más avanzadas la mayor parte del dominio estudiado alcanza o supera la resistencia obtenida por el cemento portland sin adición.

PALABRAS CLAVES: Humo de sílice; Escoria granulada de alto horno; Productos de hidratación; Resistencias mecánicas; Diseño central compuesto

Copyright: (C) 2014 CSIC. This is an open-access article distributed under the terms of the Creative Commons Attribution-Non Commercial (by-nc) Spain 3.0 License.

\section{INTRODUCTION}

The binary cements are an old component of the concrete mixtures. For more than a century, cements with granulated blast furnace slag have been produced and used in Germany, France, Luxembourg and Belgium. The pozzolanic cements were standardized in Italy at 1929, and the production of binary cement with fly ash was started in France at 1950. However, the use of mineral additions has considerably increased in the last decades due to the new requirements of the cement industry, as 
well as the need to increase the service life of concrete structures.

Since 1990, the use of ternary cements has considerably increased because they have some advantages over the binary cements (1). For this type of cements, the synergistic effect between the cement components allows to compensate partial or totally the shortcomings of any component. Additionally, they present an excellent opportunity to develop cements and concretes with less environmental impact, with adequately properties that meet the market requirement and without raising production cost (2).

In previous studies (3-7) was determined that the use of blast furnace slag, calcareous material and / or natural pozzolan, formulation of binary and ternary cement leads to a low hydration rate of the system. Consequently, there is a reduction of their mechanical and durable properties at early age when increases the replacement level of addition in cement.

When Portland cement, slag and water are mixed, the addition reacts and it can be proved by the decrease of calcium hydroxide $(\mathrm{CH})$ amount (due to the consumption by addition and/or the dilution effect) and an increase of calcium silicate hydrated (C-S-H), with similar characteristics to the compound resulting from the calcium silicates hydration of portland cement. This reaction involves two phenomenons: the grain-size and the pore-size refinement of the paste that contribute to improve the mechanical and durable properties. Due to the reaction rate is delayed and the high replacement level of slag used, the slag Portland cement has a low early mechanical strength and high strength at later ages (8).

The low early strength of slag cement can be mitigated by physical (9), thermal (10) and / or chemical activation (11), or through the incorporation of a high reactive addition, such as silica fume. Consequently, the high reaction rate of this addition combined with the stimulation effect on the portland cement hydration can partially offset the low initial hydration degree that present the cement with high blast furnace slag content.

From the mechanical point of view, the chemical effect caused by silica fume to slag cement is the main factor that increases the compressive strength at early age (12-15). In terms of durability, the ternary cements present better performance than binary cement containing blast furnace slag, because the synergic action of silica fume and blast furnace slag increases the volume of the gel decreasing the volume of capillary pores (16), with the consequent reduction of porosity and permeability. The water (17) and gases penetration is restricts and consequently the durability increases (12). Good performance of these ternary cements have been reported against to the ingress of chloride ions (18-19), to sulfate attack $(20)$, to the alkali-silica reaction $(2,21)$ and to the marine environments (22). Additionally, there is no significant change in creep and drying shrinkage (14).

Finally, the complexity of ternary cements requires further emphasize to study them as a system of interrelated variables. Due to the increase in the variable number for the rational use of these cements, it is essential to use mix design methods in order to decrease the number of experiments needed to evaluate a given property.

In this paper, the influence of the combined incorporation of silica fume and granulated blast furnace slag to portland cement on the mechanical strength and the hydration are analysed when they are curing in sealed conditions.

\section{EXPERIMENTAL PROCEDURE}

Cement and additions: For all testing, a portland cement without additions $(C P N)$ was used and its mineralogical composition according to Bogue's formula was $67 \% C_{3} S, 9 \% C_{2} S, 1 \% C_{3} A$ and $15 \%$ $C_{4} A F$. It was classified as CP42.5R strength class (f'c $>42.5 \mathrm{MPa}$ at 28 days tested on mortar prisms ISO-RILEM, EN 197-1 (23)). Silica fume (HS) and granulated blast furnace slag $(E)$ were used as mineral addition. Their chemical composition and physical properties of materials are shown in Table 1. All materials were provided by the company Loma Negra CIASA.

Blended cements: Binary and ternary cements were obtained by replacement by weight of $C P N$ by granulated blast furnace slag and silica fume. A central composite experimental design (24) was adopted to evaluate the blended cements as a system with interrelated variables and the replacement levels are derived from this selection. In this design, the two experimental variables were the percentages cement replacement by granulated slag $\left(X_{1}\right)$ and silica fume $\left(X_{2}\right)$. The experiment design could predict the response of other experimental points that are included in the studied domain, but they are not experimentally testing to obtain the model. Figure 1 shows the domain of the experimental points (black $\bullet$ ) and the fit experimental points (grey $\bullet$ ) adopted. It has six binary cements, eight ternary cements and the cement without addition $(0,0)$ resulting the final domain constituted by 15 experimental points.

Mixture proportions: The mortars were prepared maintaining a 3:1 silica sand:cementitious material ratio. To maintain the flowability of mortars at $110 \pm 5 \%$ and the water/cementitious material ratio $(w / \mathrm{cm})$ at 0.40 , a superplasticizer admixture polycarboxylate based was used $(0.9 \pm 0.1$ by weight of cementitious material) in all cases.

Curing: The prisms were kept 24 hours in the molds and then carefully demolded. Thereafter, they were wrapped with plastic film and placed in a cabinet at $20 \pm 1^{\circ} \mathrm{C}$ until testing age $(2,7,28$ and 90 days). 
TABLE 1. Chemical composition and physical properties of the materials

\begin{tabular}{|c|c|c|c|}
\hline & Portland cement $(C P N)$ & $\begin{array}{l}\text { Granulated blast } \\
\text { furnace slag }(E)\end{array}$ & Silica fume $(H S)$ \\
\hline \multicolumn{4}{|c|}{ Chemical composition, $\%$} \\
\hline $\mathrm{SiO}_{2}$ & 20.9 & 35.1 & 92.7 \\
\hline $\mathrm{Al}_{2} \mathrm{O}_{3}$ & 3.3 & 12.8 & 0.3 \\
\hline $\mathrm{CaO}$ & 64.5 & 39.1 & 0.5 \\
\hline $\mathrm{Fe}_{2} \mathrm{O}_{3}$ & 5.1 & 0.7 & 0.8 \\
\hline $\mathrm{Na}_{2} \mathrm{O}$ & 0.06 & 0.2 & 0.3 \\
\hline $\mathrm{K}_{2} \mathrm{O}$ & 1.1 & 0.5 & 0.3 \\
\hline $\mathrm{SO}_{3}$ & 2.5 & - & 0.1 \\
\hline $\mathrm{MgO}$ & 0.8 & 10.1 & 0.2 \\
\hline Loss on ignition & 1.5 & 0.89 & 0.94 \\
\hline \multicolumn{4}{|c|}{ Physical properties } \\
\hline Blaine fineness, $\mathrm{m}^{2} / \mathrm{kg}$ & 321 & 438 & 26350 \\
\hline \multicolumn{4}{|l|}{ Retained on sieve, $\%$} \\
\hline $75 \mu \mathrm{m}(\# 200)$ & 3.9 & 0.0 & - \\
\hline $45 \mu \mathrm{m}(\# 325)$ & 16.4 & 7.0 & - \\
\hline
\end{tabular}

This type of curing was selected to avoid the leaching of $\mathrm{CH}$ that occurs when samples are immersed in water.

Mechanical strength: Flexural and compressive strengths of mortar were evaluated on $40 \times 40 \times 160 \mathrm{~mm}^{3}$ specimens as specified in EN 196-1 standard (25). Results are shown in Table 2, and they correspond to the average of three and six determinations for flexural and compressive test, respectively.

Influence of additions on the hydration: To study the kinetics of reactions at very early age

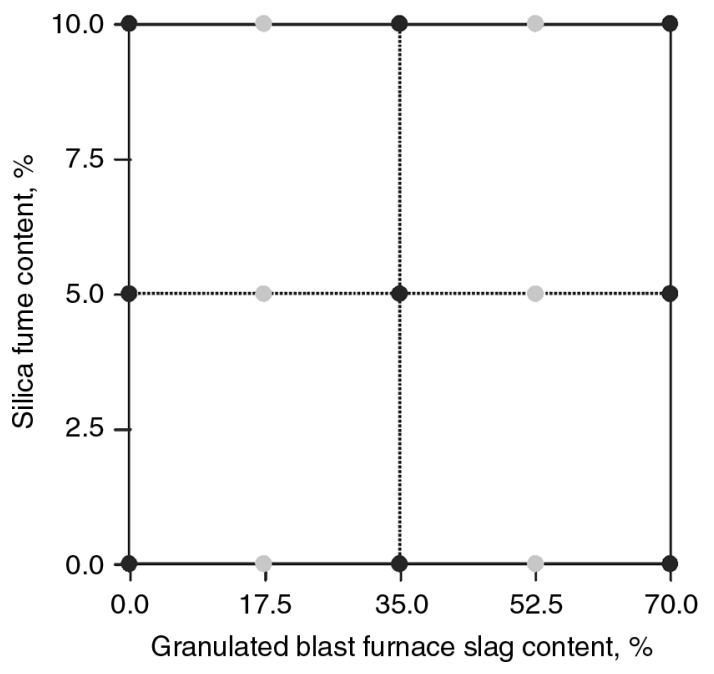

FIgURE 1. Experimental design domain.
( $<48$ hours), the development of hydration heat and the compound assembly by $X R D$ was evaluated on pastes made with the same proportion of additions that mortars and $w / \mathrm{cm}$ ratio of 0.40 . The progress of hydration at later ages was measured by the loss of water between 250 and $600{ }^{\circ} \mathrm{C}$ and the non-evaporable water on mortar.

Heat of hydration: The rate of heat released was determined in an isothermal calorimeter operating at $20{ }^{\circ} \mathrm{C}$, the amount of sample was $20 \mathrm{~g}$ and the $w / \mathrm{cm}$ of 0.40 .

$\mathrm{X}$-Ray Diffraction $(X \boldsymbol{R} D)$ : The $X R D$ measurement was made with a Philips X'Pert diffractometer equipped with graphite monochromator, using $C u K a$ radiation and operating at $40 \mathrm{kV}$ and $20 \mathrm{~mA}$.

The scan was made at $2 \%$ min rate and the step interval was $0.02^{\circ}$. The semiquantitative analysis of calcium hydroxide $(\mathrm{CH})$ was performed by the integral of the peak area at $2 \theta=18.09^{\circ}$ $(\mathrm{d}=4.90 \mathrm{~nm})$.

Water loss between 250 and $600{ }^{\circ} \mathrm{C}$ : The $\mathrm{CH}$ content could be estimated by the loss of water between 250 and $600{ }^{\circ} \mathrm{C}$. This temperature range is selected due to the AFt phases only retains three rather than 32 original molecules of water at $200{ }^{\circ} \mathrm{C}$ and the water combined in the $\mathrm{CH}$ is loosed at approximately $520^{\circ} \mathrm{C}(26)$.

Non evaporable water: To estimate the progress of hydration, non-evaporable water $(W n)$ was determined as the difference between the weight of the dried sample at $105^{\circ} \mathrm{C}(P 105)$ and the weight of calcined sample at $950{ }^{\circ} \mathrm{C}(P 950)$ subtracting 
TABLE 2. Experimental values for mechanical strength and non evaporable water

\begin{tabular}{|c|c|c|c|c|c|c|c|c|c|c|c|c|}
\hline \multirow[b]{2}{*}{ Cements } & \multicolumn{4}{|c|}{ Compressive strength, MPa } & \multicolumn{4}{|c|}{ Flexural strength, MPa } & \multicolumn{4}{|c|}{ Non evaporable water, $\%$} \\
\hline & $2 \mathrm{~d}$. & $7 \mathrm{~d}$. & $28 \mathrm{~d}$. & $90 \mathrm{~d}$. & $2 \mathrm{~d}$. & $7 \mathrm{~d}$. & $28 \mathrm{~d}$. & $90 \mathrm{~d}$. & 2 d. & $7 \mathrm{~d}$. & $28 \mathrm{~d}$. & $90 \mathrm{~d}$. \\
\hline $\mathrm{CPN}$ & 45.7 & 54.2 & 66.4 & 72.7 & 7.0 & 7.8 & 8.9 & 10.2 & 9.75 & 11.44 & 13.23 & 14.01 \\
\hline $\mathrm{CPN}+35 \mathrm{E}$ & 27.6 & 42.0 & 60.9 & 63 & 5.2 & 6.5 & 8.7 & 10.0 & 6.92 & 9.53 & 12.08 & 14.26 \\
\hline $\mathrm{CPN}+70 \mathrm{E}$ & 16.6 & 30.2 & 54.1 & 60.8 & 2.0 & 5.4 & 8.0 & 9.6 & 4.02 & 6.42 & 8.91 & 9.65 \\
\hline $\mathrm{CPN}+5 \mathrm{HS}$ & 45.5 & 64.0 & 81.7 & 87.6 & 7.5 & 8.4 & 9.3 & 10.5 & 10.52 & 11.62 & 13.81 & 14.41 \\
\hline $\mathrm{CPN}+10 \mathrm{HS}$ & 47.1 & 67.1 & 80.3 & 85.9 & 6.8 & 8.3 & 10.0 & 10.3 & 10.47 & 11.47 & 13.83 & 14.00 \\
\hline $\mathrm{CPN}+35 \mathrm{E}+5 \mathrm{HS}$ & 33.5 & 46.2 & 67.2 & 74.1 & 6.6 & 7.1 & 9.5 & 10.6 & 8.25 & 12.00 & 13.27 & 13.73 \\
\hline $\mathrm{CPN}+35 \mathrm{E}+10 \mathrm{HS}$ & 28.5 & 49.7 & 76.3 & 81 & 6.3 & 7.3 & 9.4 & 10.9 & 8.47 & 10.98 & 12.66 & 13.12 \\
\hline $\mathrm{CPN}+70 \mathrm{E}+5 \mathrm{HS}$ & 13.8 & 36.3 & 55.4 & 63.1 & 3.5 & 6.2 & 8.2 & 10.1 & 5.69 & 7.91 & 9.53 & 10.05 \\
\hline $\mathrm{CPN}+70 \mathrm{E}+10 \mathrm{HS}$ & 10.9 & 33.9 & 49.9 & 61.2 & 3.0 & 5.6 & 8.0 & 9.9 & 5.48 & 7.20 & 8.19 & 9.11 \\
\hline $\mathrm{CPN}+17.5 \mathrm{E}+5 \mathrm{HS}$ & 40.6 & 58.2 & 75.7 & 77.9 & 7.0 & 8.4 & 9.8 & 10.8 & 9.56 & 11.83 & 13.62 & 14.90 \\
\hline $\mathrm{CPN}+52.5 \mathrm{E}+5 \mathrm{HS}$ & 25.5 & 44.1 & 66.9 & 75.6 & 5.6 & 7.3 & 9.2 & 10.7 & 7.61 & 9.70 & 10.93 & 11.41 \\
\hline $\mathrm{CPN}+17.5 \mathrm{E}+10 \mathrm{HS}$ & 36.7 & 59.4 & 70.9 & 79.8 & 6.7 & 7.8 & 9.6 & 10.9 & 10.04 & 12.11 & 14.90 & 15.03 \\
\hline $\mathrm{CPN}+52.5 \mathrm{E}+10 \mathrm{HS}$ & 20.7 & 42.9 & 57.0 & 67 & 5.3 & 7.3 & 9.2 & 10.4 & 8.12 & 9.27 & 10.10 & 11.18 \\
\hline $\mathrm{CPN}+17.5 \mathrm{E}$ & 36.6 & 53.6 & 64.4 & 67.8 & 6.3 & 7.1 & 8.7 & 9.9 & 9.87 & 11.13 & 12.77 & 14.05 \\
\hline $\mathrm{CPN}+52.5 \mathrm{E}$ & 24.0 & 42.8 & 57.2 & 63.4 & 4.5 & 6.9 & 8.8 & 10.0 & 7.01 & 9.65 & 11.59 & 12.58 \\
\hline
\end{tabular}

the loss on ignition of cement $\left(P_{c} x C P N\right)$, blast furnace slag $\left(P_{E} x E\right)$, silica fume $\left(P_{H S} x H S\right)$ and sand $\left(P_{a} x A\right)$ according to percentage in the mixture. The reported value is referred to the amount of cementitious material $(m c)$ present in the sample. This term assumes that all amounts of incorporated additions react to produce $C-S-H$ [equation 1]. The results obtained are reported in Table 2.

$$
W n=\frac{P_{105}-P_{950}-\left(P_{c} x C P N+P_{E} x E+P_{H S} x H S+P_{A} x A\right)}{m c}[1]
$$

Response Surfaces: From the experimental system selected, the response surfaces of the mechanical strength and the non-evaporable water was determined using the least squares method (24). The equation [2] of this model is given as:

$$
Y=\beta_{0}+\beta_{1} X 1+\beta_{2} X 2+\beta_{3} X_{1}^{2}+\beta_{4} X_{2}^{2} \beta_{5} X_{1} X_{2}
$$

where $Y$ : is the strength or the non-evaporable water at a given age, $X_{1}$ and $X_{2}$ : are the experimental variables and $\beta_{0}, \beta_{1}, \beta_{2}, \beta_{3}, \beta_{4}, \beta_{5}$ : are the model coefficients estimated by the least squares method reported in Table 3. The correlation coefficient $\left(R^{2}\right)$ for the compressive strength and the non-evaporable water was higher than 0.91 , but it was higher than 0.85 for the flexural strength. These values indicate a good correlation between experimental and calculated values. Additionally, the analysed models showed an F-test less than 0.05 indicating that all terms of model are significant.

\section{RESULTS}

Compressive strength: Figure 2 shows the evolution of compressive strength for all cements up to 90 days. At 2 days (Figure 2a), cements with up to $10 \%$ silica fume reaches a compressive strength similar to that of $C P N$ (iso-response-curve $>42 \mathrm{MPa}$ ). On the other hand, binary cements with increasing percentage of blast furnace slag present a decrease of compressive strength attaining to a reduction of $64 \%$ for cement with $70 \%$ of slag. At this age, isoresponse curves are practically parallel to the $X_{2}$ axis showing that strength is mainly dependent of slag content in the cement. For $X_{2}=5 \%$, the ternary cements reach to the highest strength values. For example, compressive strengths of the $C P N+35 E$ and $C P N+35 E+10 H S$ cements are included by the 26-30 MPa iso-response curves, whereas strength is between $30-34 \mathrm{MPa}$ iso-response curves for the cement $C P N+35 E+5 H S$.

For blended cement with blast furnace slag content $<28 \%$ at 7 days (Figure 2b), the increase of $X_{2}$ produces the highest strength levels in ternary cements. Hence, a similar strength to $C P N$ can be achieved with values of $X_{1}=28 \%$ and $X_{2}=10 \%$ at this age. For $X_{1}>28 \%$, the strength is practically independent of the silica fume in the ternary cement. For a given replacement of slag $\left(X_{1}\right)$, the addition of silica fume $\left(X_{2}\right)>2.5 \%$ produces a similar strength level (the iso-response are equal). At 28 and 90 days (Figures 2c and $\mathrm{d}$ ), the compressive strength of binary cement with $X_{I}=70 \%$ is $18 \%(54.1 \mathrm{MPa})$ and 
TABLE 3. Models coefficients estimated by least square method and $R^{2}$ values

\begin{tabular}{|c|c|c|c|c|c|c|c|c|c|c|c|c|}
\hline \multirow[b]{2}{*}{ Coefficients } & \multicolumn{4}{|c|}{ Compressive strength, MPa } & \multicolumn{4}{|c|}{ Flexural strength, MPa } & \multicolumn{4}{|c|}{ Non evaporable water, $\%$} \\
\hline & 2 d. & $7 \mathrm{~d}$. & $28 \mathrm{~d}$. & $90 \mathrm{~d}$. & 2 d. & $7 \mathrm{~d}$. & $28 \mathrm{~d}$. & $90 \mathrm{~d}$. & $2 \mathrm{~d}$. & $7 \mathrm{~d}$. & $28 \mathrm{~d}$. & $90 \mathrm{~d}$. \\
\hline$\beta_{0}$ & 44.14 & 55.97 & 66.30 & 71.34 & 6.89 & 7.72 & 8.67 & 9.94 & 9.93 & 11.02 & 12.86 & 14.22 \\
\hline$\beta_{1}$ & -0.37 & -0.30 & -0.06 & -0.15 & $-7.05^{*}$ & -0.02 & 0.02 & 0.02 & -0.04 & 0.03 & 0.03 & 0.04 \\
\hline$\beta_{2}$ & 1.24 & 1.96 & 3.74 & 3.78 & 0.26 & 0.24 & 0.23 & 0.19 & 0.17 & 0.33 & 0.31 & 0.08 \\
\hline$\beta_{3}$ & $-0.94 *$ & -4.20 & $-1.97 *$ & $-0.39 *$ & $-0.79 *$ & $-0.22 *$ & $-0.44^{*}$ & -0.35 & $-5.88^{*}$ & $-12.9^{*}$ & $-11.6^{*}$ & $-1.43^{*}$ \\
\hline$\beta_{4}$ & -0.11 & -0.09 & -0.23 & -0.22 & -0.03 & -0.02 & -0.01 & -0.01 & -0.01 & -0.03 & -0.02 & $-7.04^{*}$ \\
\hline$\beta_{5}$ & $-5.49^{*}$ & -0.01 & -0.02 & -0.02 & $1.25^{*}$ & $-0.29 *$ & -1.56 & -0.11 & $14.2^{*}$ & $0.80^{*}$ & $-35.8^{*}$ & $-1.68^{*}$ \\
\hline $\mathrm{R}^{2}$ & 0.99 & 0.96 & 0.91 & 0.91 & 0.97 & 0.87 & 0.91 & 0.85 & 0.94 & 0.95 & 0.95 & 0.96 \\
\hline
\end{tabular}

$(*)$ the number reported* $10^{-3}$.

$16 \%(60.8 \mathrm{MPa})$ lower than that of $C P N(66.4$ and $72.7 \mathrm{MPa}$ ); while for binary cement with $X_{2}=10 \%$ the strength was $21 \%(80.3 \mathrm{MPa})$ and $18 \%$ (85.6 MPa) higher than that of $C P N$.

Finally, the maximum content of both additions that can be added to achieve to similar strength than that of $C P N$ at 28 and 90 days is $60 \%$
$\left(X_{1}=55\right.$ and $\left.X_{2}=5 \%\right)$ and $70 \%\left(X_{1}=65\right.$ and $\left.X_{2}=5 \%\right)$, respectively.

Flexural strength: Figure 3 shows the response surface for the flexural strength at 2, 7,28 and 90 days.

At 2 days (Figure 3a), binary cements with silica fume reach to greater than or equal to strength
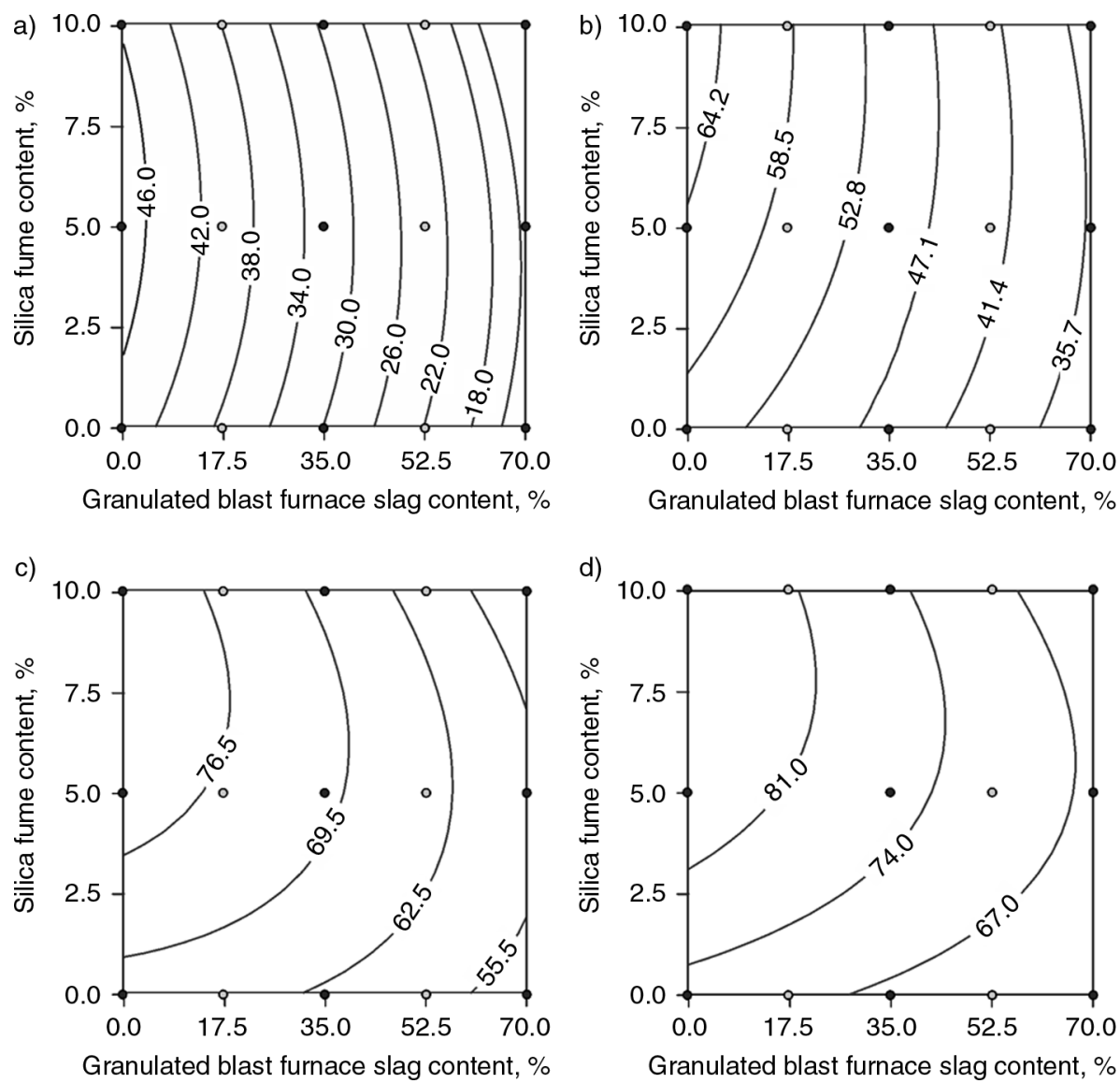

Figure 2. Compressive strength (MPa). a) 2 days $\left(R^{2}: 0.98\right)$, b) 7 days $\left(R^{2}: 0.96\right)$, c) 28 days $\left(R^{2}: 0.91\right)$ and d) 90 days $\left(R^{2}: 0.91\right)$. 

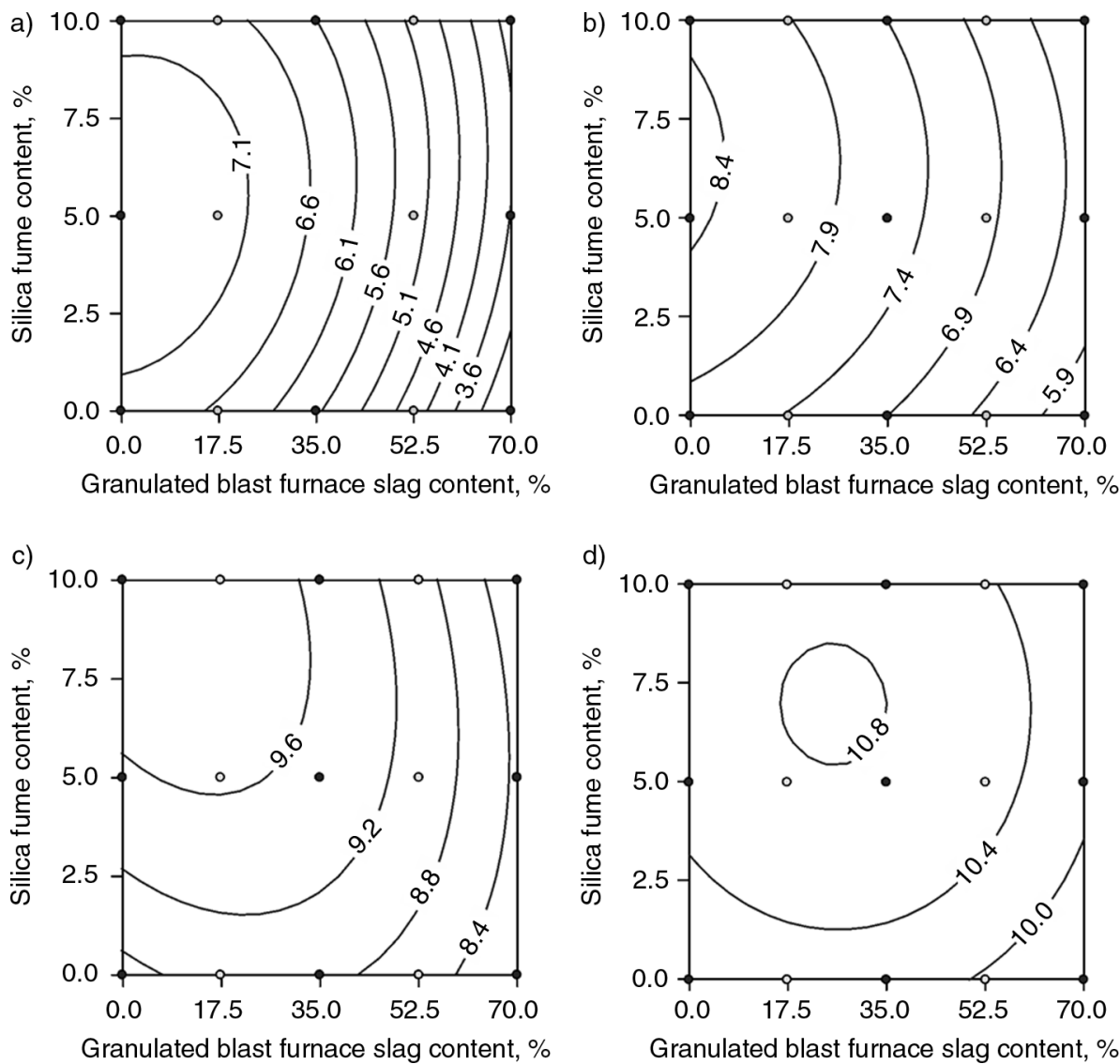

FIGURE 3. Flexural strength (MPa). a) 2 days $\left(R^{2}: 0.97\right)$, b) 7 days $\left(R^{2}: 0.87\right)$, c) 28 days $\left(R^{2}: 0.91\right)$ and d) 90 days $\left(R^{2}: 0.85\right)$.

obtained by $C P N(>6.60 \mathrm{MPa})$. For this flexural strength value, the maximum percentage of blast furnace slag that can be incorporated into the binary cement is $17 \%$. For $X_{I}>35 \%$, the strength of binary cement shows a strong dependence on the $X_{I}$-value and the iso-response curves are closer, indicating that a small increase of slag content produces a low strength.

Regarding the ternary cements, they exhibit a similar behaviour that it was described in compressive strength. For a given value of $X_{1}$, the flexural strength was greater when $X_{2}=5 \%$. At this age, the $C P N$-strength can be achieved for values of $X_{I}=30 \%$ and $X_{2}=5 \%$. At 7 days (Figure 3b), the behaviour of ternary cements is similar to that observed at 2 days, with a slight increase in the level of additions to achieve to the $C P N$ strength $\left(X_{1}=40 \%\right.$ and $\left.X_{2}=5 \%\right)$. At 28 and 90 days, the flexural strength of all experimental blended cement is between $9.0 \pm 1.0 \mathrm{MPa}( \pm 11 \%)$ and $10.2 \pm 0.6 \mathrm{MPa}$ $( \pm 5.9 \%)$, respectively. At 28 days, the circumscribed area limited by the iso-response curve of $8.4 \mathrm{MPa}$ attains to values of $X_{1}<65 \%$ and $X_{2}<10 \%$ (Figure 3c). At 90 days, the bounded area limited by the curve $10 \mathrm{MPa}$ can be obtained for values of $X_{1}<70 \%$ and $X_{2}>3.5 \%$ (Figure $3 \mathrm{~d}$ ).
Heat of hydration: Figure 4 shows the evolution of the heat release rate during the first 48 hours of hydration and Table 4 reports the time of occurrence of the maximum peak and the cumulative heat at this age. For binary cements with blast furnace slag (Figure 4a), it can be seen that as the percentage of replacement of the addition increases, the rate of heat release, the maximum intensity of peak and the cumulative heat developed at 48 hours decreases. However, the occurrence time for the maximum does not significantly change; all values are $950 \pm 10$ min (Table 4). For binary cements made with silica fume (Figure 4b), can be observed that the increase of replacement percentage produces an acceleration of the hydration respect to $C P N$ paste. There is an increase of the maximum intensity of peak and the cumulative heat developed at 48 hours, while the occurrence time of maximum has slightly in advance (Table 4).

Ternary cements present an intermediate behaviour between the both binary cements evidencing the synergic action of additions. For example, the $C P N+35 E+5 H S$ (Figure 4c) shows the decrease of heat released caused by blast-furnace slag and the acceleration produced by silica fume, resulting from 
a)

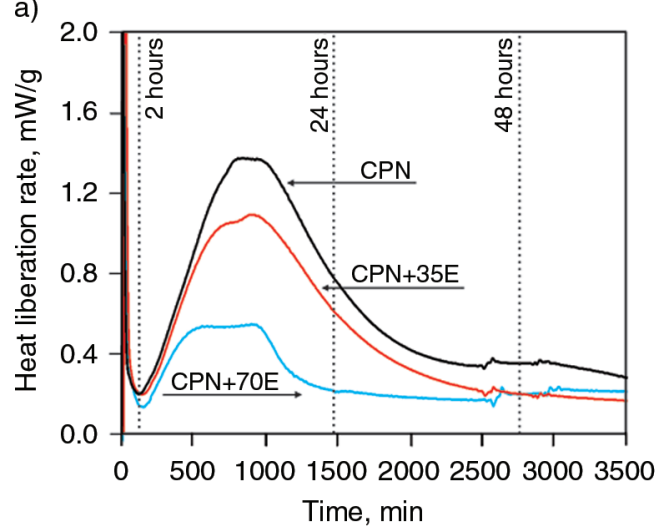

c)

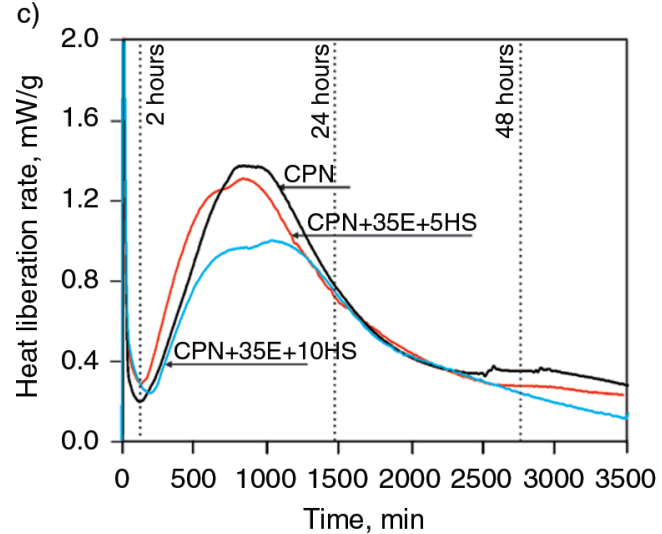

b)

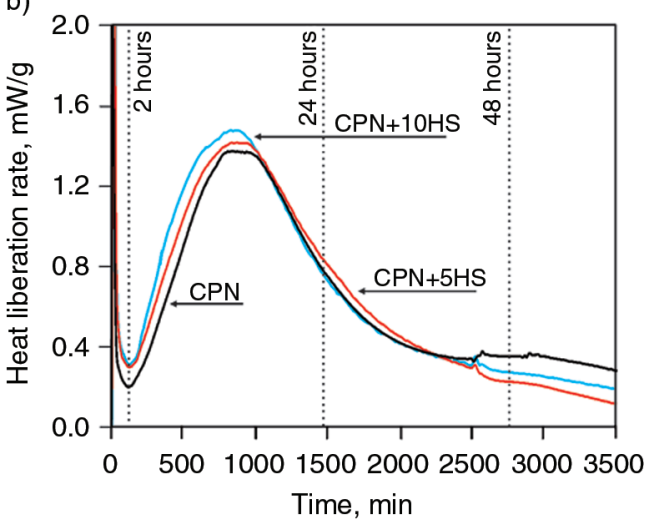

d)

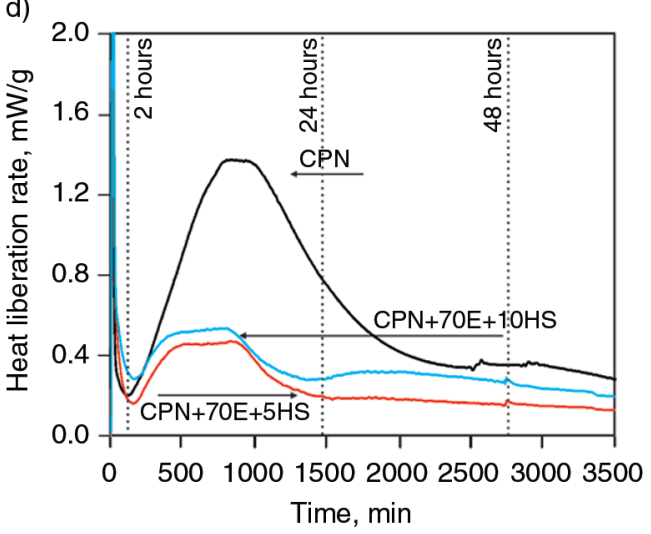

FIGURE 4. Heat released rate vs time curve. a) binary cements with slag, b) binary cements with silica fume, c) ternary cements with $35 \%$ blast furnace slag and silica fume and d) ternary cements with $70 \%$ blast furnace slag and silica fume.

their interaction an increase of the maximum intensity peak and slight delays $(6 \%)$ of its occurrence time compared with the $C P N+35 E$. Cements with $70 \%$ blast furnace slag and silica fume (Figure 4d) show the same synergic effect. When increase the silica fume content, the maximum intensity of the curves increases as well as its occurrence time is in advance.

TABLE 4. Results from the heat of hydration test

\begin{tabular}{lcc}
\hline Cements & $\begin{array}{c}\text { Time of maximum } \\
\text { peak, min }\end{array}$ & $\begin{array}{c}\text { Cumulative heat at } \\
\mathbf{4 8} \text { hours, } \mathbf{k J} / \mathbf{k g}\end{array}$ \\
\hline CPN & 960 & 126 \\
CPN+35E & 945 & 98 \\
CPN+70E & 940 & 56 \\
CPN+5HS & 910 & 144 \\
CPN+10HS & 875 & 128 \\
CPN+35E+5HS & 885 & 102 \\
CPN+35E+10HS & 850 & 86 \\
CPN+70E+5HS & 850 & 40 \\
CPN+70E+10HS & 810 & 45 \\
\hline
\end{tabular}

X-Ray Diffraction: Figure 5 shows the diffractograms obtained from pastes at 2, 24 and 48 hours and Table 5 reports the results of the quantification of the $C H\left(2 \theta=18.09^{\circ}, d=4.90 \mathrm{~nm}\right)$.

For $C P N$ paste, the hydration products detected by $X R D$ were: $C H$ and ettringite (Figure $5 \mathrm{a}$ ) and the $\mathrm{CH}$-content increases 20 times from 2 to 48 hours (Table 5). For binary cements with blast furnace slag, it could be observed a less $\mathrm{CH}$-content when the addition content increases. After 24 hours, a similar phase to hydrotalcite (27-28) can be detected derived from the reaction of magnesium containing in the blast furnace slag (Figures $5 \mathrm{~b}$ and c). For binary cements with silica fume (Figures $5 \mathrm{~d}$ and e), a decrease of $\mathrm{CH}$-content can be observed when the percentage of addition increases. However, all binary cements have high $\mathrm{CH}$-content at 2 hours evidencing the stimulation effect on the hydration reaction of cement (Table 5).

At 2 hours, ternary cements containing 35\% of blast furnace slag and silica fume (Figures $5 f$ and g) have $\mathrm{CH}$ and ettringite, whereas any crystalline hydration products could be detected for ternary cement with $70 \%$ slag furnace and silica fume (Figures $5 \mathrm{~h}$ and i). After 24 hours, the $\mathrm{CH}$ peaks 

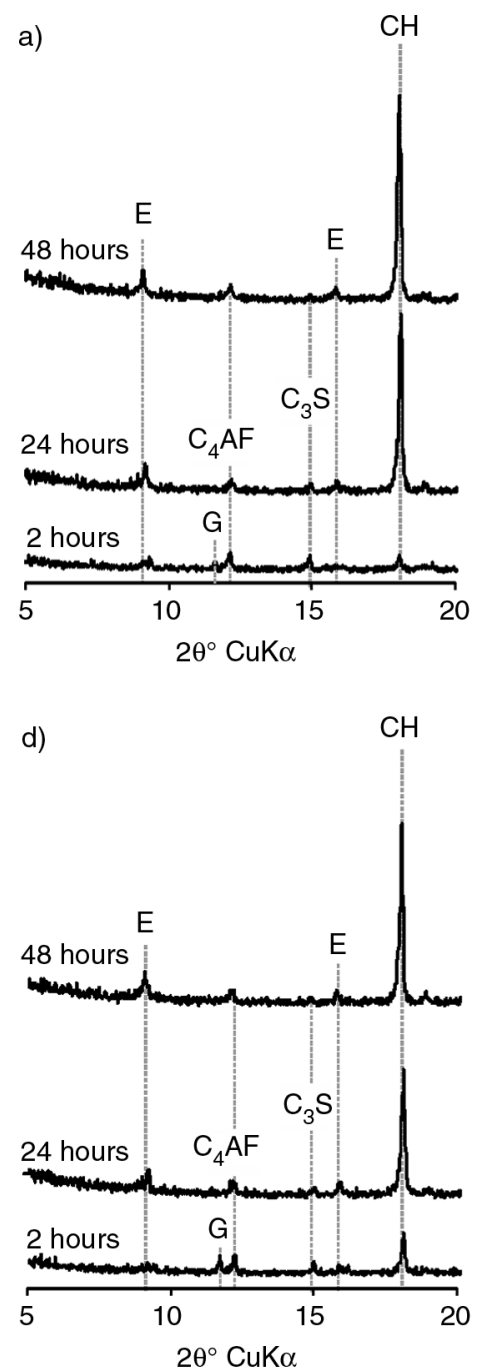

g)

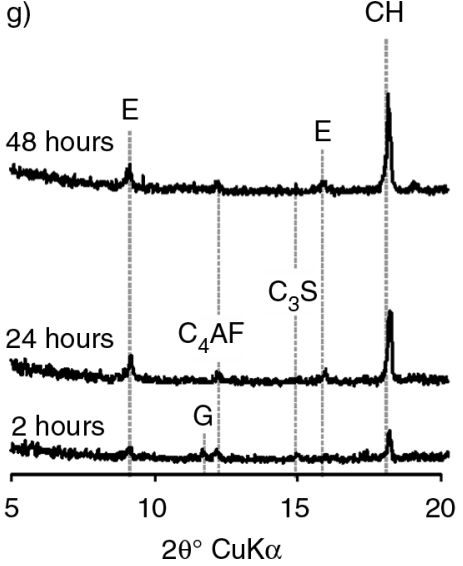

b)

c)
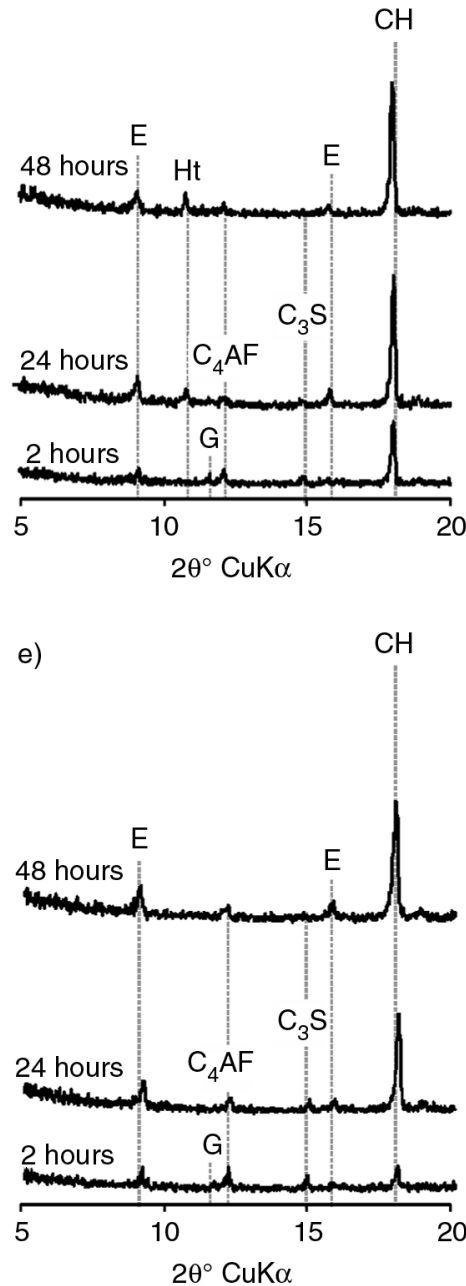

h)

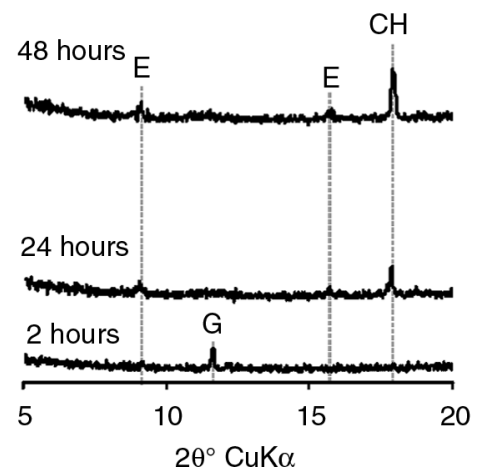

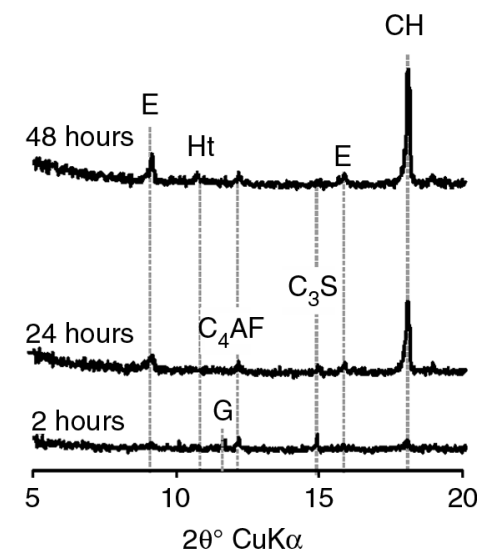

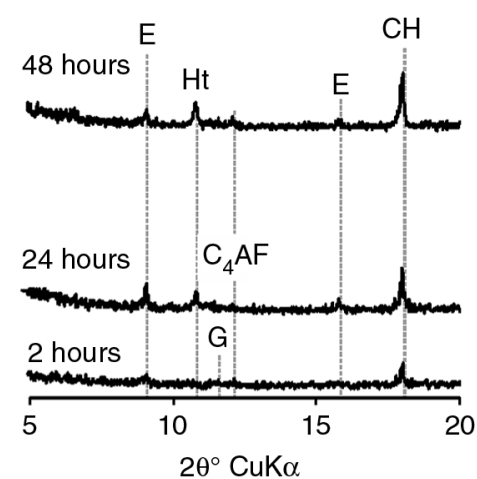

f)

i)

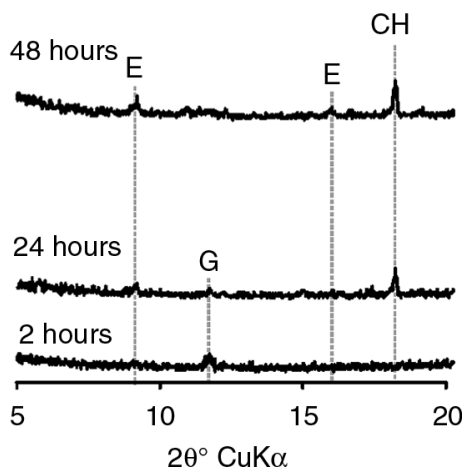

Figure 5. XRD patterns at 2, 24 and 28 hours for pastes. a) $C P N$, b) $C P N+35 E$, c) $C P N+70 E$, d) $C P N+5 H S$, e) $C P N+10 H S$, f) $C P N+35 E+5 H S$, g) $C P N+35 E+10 H S$, h) $C P N+70 E+5 H S$ and i) $C P N+70 E+10 H S$. E: etringite, G. gypsum, Ht: hydrotalcite.

appear with low intensity due to the high percentage of replacement and they have an increasing intensity with time. The hydrotalcite like phase was only observed at 24 hours for $C P N+35 E+5 H S$ paste evidencing that interaction of slag and silica fume delays the crystallization of this compound. 
TABLE 5. Semiquantitative analysis of peak $C H(2 \theta$ : $\left.18.09^{\circ}, d: 4.90 \mathrm{~nm}\right)$, en cps

\begin{tabular}{|c|c|c|c|c|}
\hline \multirow[b]{2}{*}{ Cements } & \multicolumn{3}{|c|}{ Age, hours } & \multirow{2}{*}{$\begin{array}{c}\text { Relative } \\
\text { values for } 48 \\
\text { hours, \% (*) }\end{array}$} \\
\hline & 2 & 24 & 48 & \\
\hline CPN & 3.5 & 58.5 & 74.4 & 100 \\
\hline $\mathrm{CPN}+35 \mathrm{E}$ & 18.2 & 39.6 & 56.4 & 117 \\
\hline $\mathrm{CPN}+70 \mathrm{E}$ & 6.1 & 16.4 & 24.1 & 108 \\
\hline $\mathrm{CPN}+5 \mathrm{HS}$ & 10.6 & 43.8 & 60.8 & 86 \\
\hline $\mathrm{CPN}+10 \mathrm{HS}$ & 5.2 & 30.6 & 37.3 & 56 \\
\hline $\mathrm{CPN}+35 \mathrm{E}+5 \mathrm{HS}$ & 2.5 & 20.1 & 44.9 & 101 \\
\hline $\mathrm{CPN}+35 \mathrm{E}+10 \mathrm{HS}$ & 6.4 & 21.1 & 36.9 & 90 \\
\hline $\mathrm{CPN}+70 \mathrm{E}+5 \mathrm{HS}$ & 0 & 8.7 & 17.9 & 96 \\
\hline $\mathrm{CPN}+70 \mathrm{E}+10 \mathrm{HS}$ & 0 & 6.6 & 11.9 & 80 \\
\hline
\end{tabular}

$(*)$ Relative values to the amount of cement present in the sample, for example calculating for paste $C P N+35 E$ is: $(\operatorname{cps}(C P N+35)$ $10.65 \times$ cps $(C P N)) \times 100=(56.4 \mathrm{cps} / 0.65 \times 74.4 \mathrm{cps}) \times 100=117 \%$.

Additionally, any AFm phases (monosulfoaluminate and carboaluminate hemihydrate) were detected in pastes and it is attributed to the low content of $C_{3} A$ in cement pastes (29).
Water loss between 250 and $600{ }^{\circ} \mathrm{C}$ : Figure 6 shows water loss evolution between 250 and $600{ }^{\circ} \mathrm{C}$ expressed as per gram of portland cement.

For binary cements with blast furnace slag (Figure 6a), it can be seen that the water loss is greater than that of obtained in $C P N$ at early age. At 28 and 90 days, this parameter slightly decreases ( 5 to $7 \%$ ) for $C P N+70 E$ cement. For binary cements with silica fume (Figure 6b), the water loss was lower than those obtained in $C P N$ at all ages. For example, this parameter for $C P N+5 H S$ and $C P N+10 H S$ reach to values of 8 and $13 \%$ lower than that observed in $C P N$ at 2 days, while they were 11 and $15 \%$ lower at 90 days, respectively. Finally, for ternary cements (Figures 6c and d), water loss has a values between those obtained for binary cements with blast furnace slag or with silica fume.

At 2 days, similar results are obtained for the $\mathrm{CH}$-content reported in Table 5 where it is referred to the amount of portland cement present in the sample. Pastes with 35 and $70 \%$ of blast furnace slag have a high relative $\mathrm{CH}$-content (117 and $108 \%$ ) and pastes with 5 and $10 \%$ of silica fume has low relative $\mathrm{CH}$-content ( 86 and $56 \%$ ). Ternary cements reach to relative $\mathrm{CH}$-content a)

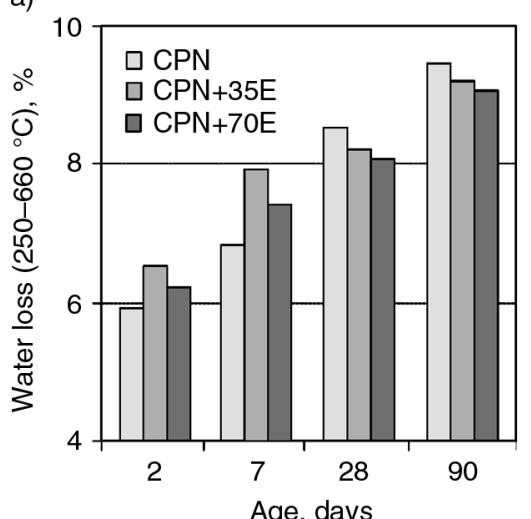

c)

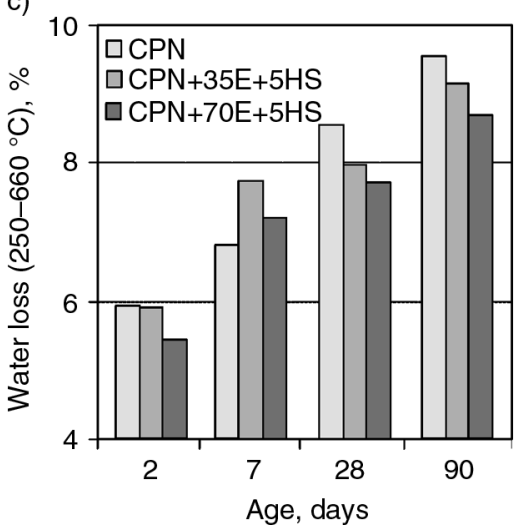

b)

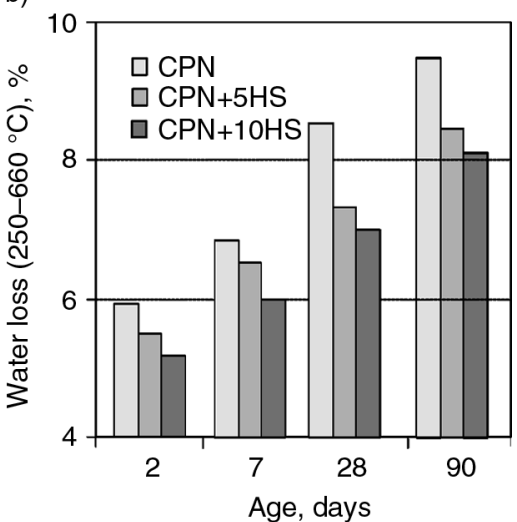

d)

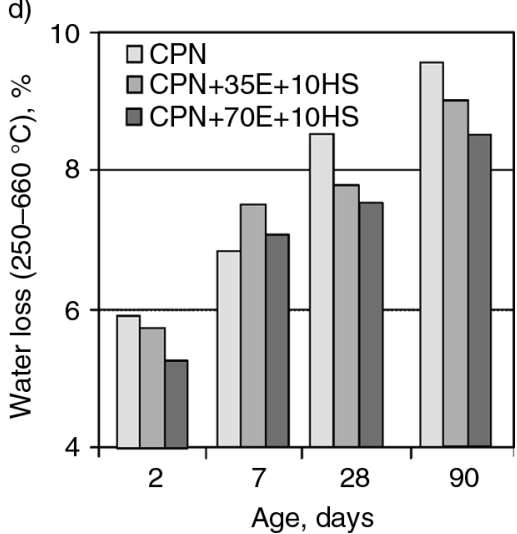

Figure 6. Water loss between 250 and $600^{\circ} \mathrm{C}$ ( $\mathrm{CH}$-content estimated) referred to the amount of portland cement in the sample. a) binary cement with blast furnace slag, b) binary cement with silica fume, c) ternary cement with $5 \%$ silica fume and blast furnace slag and d) ternary cement with $10 \%$ silica fume and blast furnace slag. 
between the values obtained for samples prepared with binary cements.

\section{DISCUSSSION}

The strength obtained for binary and ternary cements is a function of: stimulation effect (acceleration of hydration) that produces the additions on the portland cement, the differential reaction rates of additions and, the dilution effect in the blended cement. The simultaneous action of these effects determines the type and amount of hydration products in the system, and consequently the pore microstructure and the mechanical strength of samples.

For slag binary cements, the addition has $60 \%$ of particles larger than $10 \mu \mathrm{m}$ and $7 \%$ higher than $45 \mu \mathrm{m}$ and thereafter the main contribution to hydration and strength will be expected after 7 days (30). Consequently, the behaviour at early age can be firstly attributed to the dilution effect that causes a decrease in the rate of heat release and secondly to the stimulation effect that accelerates the hydration of portland cement phases producing a large amount of $C-S-H$ and $C H$ (31) (Table 5 and Figure 6).
At later ages, the decrease of water loss at 28 days could be due to the stimulation effect is less important for binary cements with blast furnace slag. More than $73 \%$ of $C P N(W n: 13.23 \%)$ has reacted and some part of $\mathrm{CH}$ has been consumed during the reaction of the blast furnace slag (32). Thus, to achieve a compressive strength to that $C P N$, the slag replacement can be up to $17.5 \%$ at early age and it increases up to $35 \%$ at later ages.

For binary cements with silica fume, the initial hydration of addition and the stimulation effect are more important than the dilution effect (33) up to 48 hours. The rate and the intensity of heat peak (Figure $4 \mathrm{~b}$ ) increase for cements with silica fume and the $\mathrm{CH}$-content (Table 5, Figure 6) is lower than that of $C P N$. Consequently, cement with silica fume present higher strength than that of $C P N$ since the early age.

The synergy action between both additions causes a decrease in the $\mathrm{CH}$-content (Table 5), a quit initial hydration and an advance of the occurrence time of the maximum heat peak (Table 4). These effects of silica fume addition can partially compensate the dilution effect caused by the blast furnace slag addition in ternary cements. Then, a large content of a)

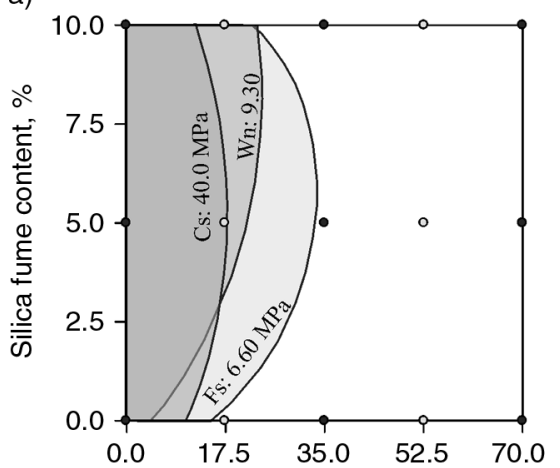

Granulated blast furnace slag content, \%

c)

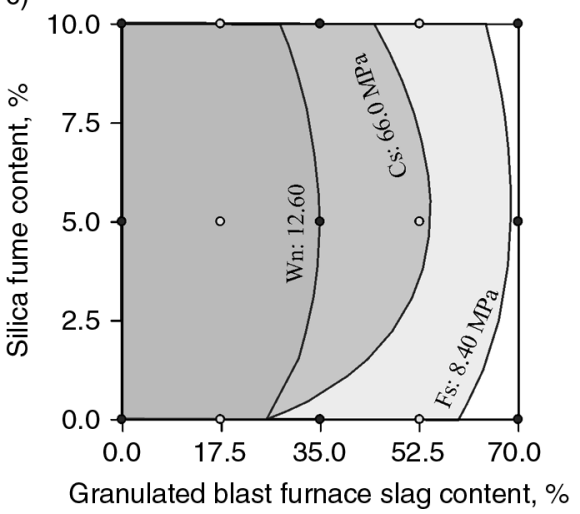

b)

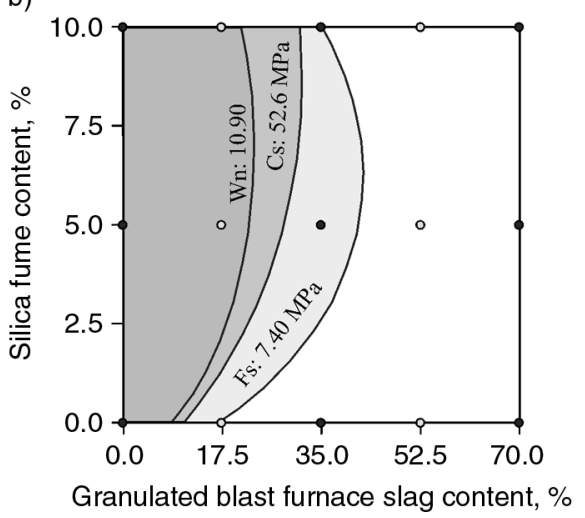

d)

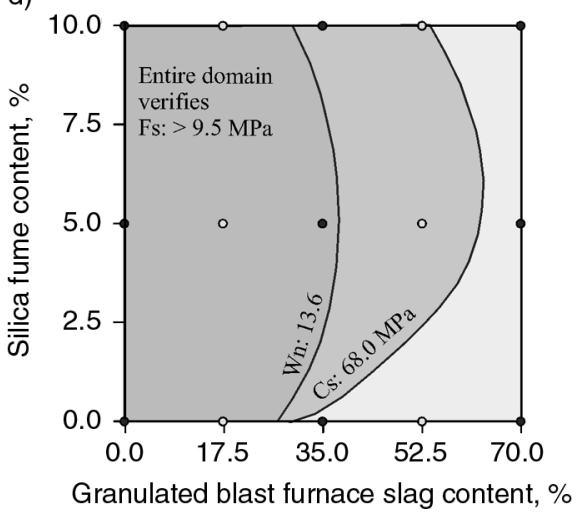

FIGURE 7. Overlaid response surfaces to attain a response value greater than or equal to those of $C P N$ at: a) 2 days, b) 7 days, c) 28 days and d) 90 days. 
blast furnace slag can be incorporated to the blended cement to attain a similar strength to that obtained for $C P N$. This effect is more important at early age (2 to 7 days) and to obtain the same mechanical strength, the iso-response area (Figures $3 a$ and b, 4a and b) for ternary cement containing 5\% silica fume allows the incorporation of twice amount of blast furnace slag.

In Figure 7, it can be observed the overlaid iso-response surfaces of the compressive, flexural strength and non-evaporable water content with relative values greater than $95 \%$ of the corresponding to the $C P N$ value. It can be seen that for this imposed condition, each studied property defines a different percentage range of additions. For example, to obtain a compressive and flexural strength equal to or greater than 0.95 that of $C P N$ at 2 days, the ternary cement could be incorporate up to $17.5 \%$ of blast furnace slag $+5 \%$ silica fume, and $35 \%$ of blast furnace slag $+5 \%$ silica fume, respectively.

A 90 days (Figure $7 d$ ), the entire studied domain has a flexural strength greater than 0.95 of $C P N$, and ternary cements with $X_{1}<65 \%$ and $X_{2}<5 \%$ have a compressive strength greater than 0.95 of $C P N$. Consequently, the content of additions that could be incorporated for this objective is greater for flexural strength compared with respect to compressive strength at all ages evidencing that additions produce a more significant improvement on the flexural strength. This behaviour is attributed firstly to the replacement of large and oriented crystals of the $\mathrm{CH}$ by small and few oriented crystals (34) and, secondly, to the increase in the compactness of matrix and the interface due to the pore size refinement (30).

Finally, a similar mechanical strength to the $C P N$ can be achieved with a low non-evaporable water content for binary and ternary cements and consequently the low hydration degree of blended cements can be compensated by the more dense and homogeneous microstructure (35).

\section{CONCLUSIONS}

According to the results obtained from pastes and mortars made with portland cement, blast furnace slag $(0-70 \%)$ and silica fume $(0-10 \%)$, it can be concluded that:

- Due to the quit reaction rate of silica fume with $\mathrm{CH}$ produced by cement hydration, it is possible to increase the average level of addition of blast furnace slag in the blended cement to achieve the same mechanical strength that of $C P N$ at early age. At later ages, the incorporation of silica fume in the cement - blast furnace slag system allows to duplicate the slag contents attaining to the same strength level. Hence, the mechanical strength for all blended cement with up to $5 \%$ of silica fume and up to $65 \%$ of granulated blast furnace slag is greater than or equal to $95 \%$ of strength of $C P N$.
- A similar mechanical behavior to the $C P N$ can be obtained with a lower content of nonevaporable water for cements with additions due to the dense matrix obtained.

\section{REFERENCES}

1. Elkhadiri, I.; Diouri, A.; Boukhari, A.; Aride, J.; Puertas, F. (2002) Mechanical behaviour of various mortars made by combined fly ash and limestone in Moroccan portland cement, Cem. Concr. Res. 32, [5], 1597-1603. http://dx.doi. org/10.1016/S0008-8846(02)00834-7.

2. Nedhi, M. (2001) Ternary and quaternary cements for sustainable development, Concrete International. 23, [4], pp. 35-42.

3. Menéndez, G.; Bonavetti, V.L.; Irassar, E.F. (2003) Stength development of ternary blended cement with limestone filler and blast-furnace slag, Cem. Concr. Comp. 25, [1], 57-63. http://dx.doi.org/10.1016/S0958-9465(01)00056-7.

4. Carrasco, M.F; Menéndez, G.; Bonavetti, V.L.; Irassar, E.F. (2003) Strength Optimization of "Tailor Made Cement" with Limestone Filler and Blast Furnace Slag, Cem. Concr. Res. 351324-1331. http://dx.doi.org/10.1016/j. cemconres.2004.09.023

5. Bonavetti, V.L.; Menéndez, G.; Donza, H.A.; Rahhal, V.F.; Irassar, E.F. (2006) Composite cements containing natural pozzolan and granulated blast furnace slag, Mater Construcc. 56, [283], 25-36. http://dx.doi.org/10.3989/ mc.2006.v56.i283.6.

6. Menéndez, G.; Bonavetti, V.L.; Irassar, E.F. (2007) Ternary blend cements concrete. Part II: Transport mechanism, Mater Construcc. 57, [285], 31-43. http://dx.doi.org/10.3989/ mc.2007.v57.i285.37.

7. Bonavetti, V.L. (2004) Hormigón con elevado contenido de adiciones (Green Concrete). Hormigones Especiales. Editado por la Asociación Argentina de Tecnología del hormigón. 97-142.

8. ACI 233, (1998) Ground Granulated Blast-Furnace Slag as a Cementitious Constituent in Concrete, ACI Manual of Concrete Practice, Part 1, Materials and General Properties of Concrete.

9. Castellano, C.; Bonavetti, V.L.; Irassar, E.F. (2008) Efecto de la finura de la escoria sobre el mecanismo de hidratación de pastas cementos mezcla a distintas temperaturas, $17^{\mathrm{a}}$ Reunión Técnica de la Asociación Argentina del Hormigón. 355-362, Córdoba, Argentina. Octubre.

10. Castellano, C.; Bonavetti, V.L.; Irassar, E.F. (2007) Efecto de la temperatura de curado sobre la resistencia de pastas de cemento con escoria granulada de alto horno, Revista de la Construcción Escuela de Construcción Civil Pontificia Universidad Católica de Chile. 6, [2], 4-15.

11. Fernández-Jimenez, A.; Puertas, F.; Arteaga, A. (1998) Determination of kinetic equations of alkaline activation of blast furnace slag by means of calorimetric data, $J$. Therm. Anal., 52, 945-955.

12. Campbell, G.M.; Detwiler, R. (1993) Development of mix designs for strength and durability of steam-cured concrete, Concrete International, 15, 37-39.

13. Jianyong, L.; Pei, T. (1997) Effect of slag and silica fume on mechanical properties of high strength concrete, Cem. Concr. Res, 27, [6], 833-837. http://dx.doi.org/10.1016/ S0008-8846(97)00076-8.

14. Khatri, R.P.; Sirivivatnanon, V. (1995) Effect of different supplementary cementitious material son mechanical propierties of high performance concrete, Cem. Concr. Res, 25, [1], 209-220. http://dx.doi.org/10.1016/0008-8846 (94)00128-L.

15. Lane, D.S.; Ozyildirim, C. (1999) Preventive measures for alcali-silica reactions (binary and ternary systems), Cem. Concr. Res, 29, [8], 1281-1288. http://dx.doi.org/10.1016/ S0008-8846(98)00242-7.

16. Guerra Gastaldini, A.L.; Fontinelli Rosses, M.; Pedroso Saciloto, A.; Bilhalva, A.M. (1997) Influence of the minerals admixture in the porosity of portland cement paste, 
XXVIII Jornadas Sul-Americanas de Engenharia estructural, [5], pp. 2119-2128, Sao Carlos Brasil.

17. Bágel, L. (1998) Strength and pore structure of ternary blended cement mortars containing. Blast furnace slag and silica fume, Cem. Concr. Res, 28, [7], 1011-1020. http:// dx.doi.org/10.1016/S0008-8846(98)00078-7.

18. Wee, T.H.; Suryavanshi, A.K.; Tin, S.S. (2000) Evaluation of rapid chloride permeability test (RCPT). Results for concrete containing mineral admixtrures, ACI Materials Journal. [97], 221-232.

19. Ozyldirim, C. (1994) Laboratory investigation of lowpermeability concretes containing slag and silica fume, ACI Materials Journal, 91, [2], 197-202.

20. Fidjestol, P.; Frearson, J. (1994) High-performance concrete using blended and triple blended binders, Proc ACI SP 149, High-Performance Concrete, International Conference Singapore, 135-157.

21. Hekal, E.E.; Kishar, E.; Mostafa, H. (2002) Magnesium sulfate attack on hardened blended cement pastes under different circumstances, Cem. Concr. Res, 32, [9], 1421-1427. http://dx.doi.org/10.1016/S0008-8846(02)00801-3.

22. Polder, R.B. (1996) Influence of blast furnace slag, fly ash and silica fume on corrosion of reinforced concrete in marine environment, Heron, 41, [4], 287-300.

23. EN 197-1. (2000) Parte 1: Composición, especificaciones y criterios de conformidad de los cementos comunes

24. Montgomery, D.; Runger, G. (1996) Probabilidad y Estadística Aplicadas a la Ingeniería, Mc Graw Hill, México, 787.

25. Norma EN 196-1. (2005) Métodos de ensayos de cementos. Parte I: Determinación de resistencias mecánicas.

26. Lea, F.M. (1971) The chemistry of cement and concrete, Chemical Publishing Co, Inc.
27. Ramlochan, T.; Thomas, M.D.A.; Hooton, R.D. (2004) The effect of pozzolans and slag on the expansion of mortars cured at elevated temperature. Part II: Microstructural and microchemical investigations, Cem. Concr. Res, 34, [8], 1341-1356. http://dx.doi.org/10.1016/j.cemconres.2003. 12.026 .

28. Massazza, F.; Daimon, M. (1992) Chemistry of Hydration of Cements and Cementitious Systems, 9 Th ICCC, I, 383-446, New Delhi, India.

29. Chen, W.; Brouwers, H.J.H. (2007) The hydration of slag, part 1: reaction models for alkali-activated slag, Journal of Material Science, [42], 428-443. http://dx.doi.org/10.1007/ s10853-006-0873-2.

30. Metha, P.K.; Monteiro, P.J.M. (1993) Concrete Structure, Properties, and Materials, Second Edition. Prentice-Hall, Inc. Englewood, Cliffs. New Jersey.

31. Zhang, C.; Wang, A.; Tang, M.; Liu, X. (1996) The Filling Role of Pozzolanic Material, Cem. Concr. Res, 26, [6], pp. 943-947. http://dx.doi.org/10.1016/0008-8846(96)00064-6.

32. Detwiler, R.J.; Krishnan, K.; Mehta, P.K. (1987) Effects of Granulated Blast Furnace Slag on the Transition Zone in Concrete, Katharine and Bryant Mather International Conference, ACI SP 100, 1, 63-72.

33. Rahhal, V.F. (2002) Caracterización de las adiciones puzolánicas por calorimetría de conducción, Tesis Doctoral, Univerdidad Polictécnica de Madrid, España, 608.

34. Giaccio, G.; Giovanbattista, A.; Zerbino, R. (1991) Propiedades de los hormigones elaborados con alto volumen de puzolanas naturales, Hormigón. [20], 5-14.

35. Stark, J.; Ludwig, H.M. (1997) Freeze-Thaw and FreezeDeicing Salt Resistance of Concretes Containing Cement Rich in Granulated Blast Furnace Slag, ACI Materials Journal. 94, [1], 47-55. 